\title{
Can Hybrid Learning Supplant the Brick-and-Stone Classroom in Teaching "Strategies for Academic Success in College"? A Focus Assessment Study
}

\author{
Laurice E. Damo ${ }^{1}$, Reynold C. Padagas ${ }^{2, *}$ \\ ${ }^{1}$ College of Liberal Arts, Criminology and Education, Jose Rizal University, Philippines \\ ${ }^{2}$ College of Nursing and Allied Health Sciences, Jose Rizal University, Philippines
}

Received December 20, 2019; Revised April 8, 2020; Accepted April 27, 2020

Copyright $\mathrm{C} 2020$ by authors, all rights reserved. Authors agree that this article remains permanently open access under the terms of the Creative Commons Attribution License 4.0 International License

\begin{abstract}
Hybrid learning is an intentional integration of traditional and online learning in order to provide educational opportunities that maximize the benefits of each mode of delivery to facilitate students' learning. Institutions of higher learning are being challenged to adopt such modality to deliver quality instruction. This descriptive-exploratory research assessed hybrid learning as a technology-aided tool employed in Freshmen Orientation Seminar (FOS) C101, known as "Strategies for Academic Success in College," a distinct and unique course offered among first year students of a private, non-sectarian university in the Philippines. This study involved 40 students from various courses. Results showed high assessments of the hybrid learning dimensions, namely, learning design, learning objectives and outcomes, learning materials, technology, learning support, administrative and organizational commitment, amount and quality of interaction between teachers and students, and quality and amount of learning experience. Further, the null hypothesis stating that no significant differences exist in the assessment of student-respondents about the aforementioned dimensions of hybrid learning when they are grouped according to their profile variables was confirmed. Generally, the findings may contribute to the enhancement of the modality of instruction of FOS C101. Several recommendations are made to maximize hybrid learning as a tool of teaching.
\end{abstract}

Keywords Academic Success, Hybrid Learning, Innovation, Traditional Classroom

\section{Introduction}

The world is becoming more responsive to diverse kinds of learners through the adoption of technology and innovative teaching and learning delivery measures. There is nothing new under the sun, but there are lots of old methods left undiscovered until the time that technology drastically influenced the ways education is delivered and facilitated. Technology moves the capacities of various higher education institutions across the world, and countries cannot settle for less but be at par in its utilization to impact quality teaching and learning. The rapid development of technology has a significant effect on society, and it is observable that different educational institutions are influenced by technology. Many countries in the Asia Pacific give value to the integration of technology in education. As technology is further advanced, an educational technology called hybrid learning has been adopted. Hybrid learning is a formal educational program that combines traditional classroom teaching methods with digital media, where students' face-to-face education is blended with Internet resources or online courses. It has been gaining considerable attention in education reform circles and entangled with the ambiguous notion of personalized learning and is being positioned as a new way to individualized learning.

Transitioning away from seat time, in favor of a structure that creates flexibility, allows students to progress as they demonstrate mastery of academic content, regardless of time, place, or pace of learning. By enabling students to master skills at their own pace, hybrid learning aims to save both time and money through the use of technology, support new patterns that utilize teacher skills and interests differently.

In the United States, the Southern New Hampshire University (SNHU) has been very aggressive in the use of an online learning environment through hybrid learning. The SNHU became the world's most drastic online education provider across the globe (LeBlanc, 2019, April 
5). In the United Kingdom, there is also a massive increase in the demand for hybrid learning to cater to the diverse needs of learners in an "anytime, anywhere" kind of learning. It can be posited that the world responds to the rapidly changing education landscape that cares for quality and fulfilling education experiences for both the learners and teachers.

The Philippine educational system has been a witness to many educational shifts ranging from mere subject-based learning to knowledge acquisition and application, from memorization to higher-order process of thinking and learning, among others. As a result of this, various curricular approaches and strategies like hybrid learning have been introduced and implemented which include activity-based and conceptualization strategy, values integration, career spotlighting, application of concepts, application of life skills, integrative model of teaching, collaborative teaching strategy, and provision of varied activities that address students' multiple intelligences. Moreover, alternative and user-friendly instructional materials have been introduced like modules, self-learning kits, and other learning packages.

Hybrid learning in curricular approaches and strategies has been anchored on the different learning theories postulated by cognitivism, and constructivists. In the context of theories of learning which focus on the active involvement of learner, teaching becomes a process of facilitation of student learning, rather than one of supplying knowledge to a passive learner. As views of the learning process have evolved, technological developments have offered means by which student-centered learning methodologies can be more effectively implemented.

In the University where the researchers are connected, several courses have adopted hybrid learning. For instance, FOS C101 is a 3-unit course, also known as Strategies for Academic Success in College. This is a unique course only offered by Jose Rizal University (JRU) to help college students succeed in their chosen fields of specialization in their baccalaureate degrees. The course description cites that FOS C101 is a seminar orientation course that introduces college students to college-level thinking skills, interpersonal skills, and practical study skills necessary for success in college. The purpose of this course is to assist entering first year students in adjusting to college life and to enhance their knowledge of Jose Rizal University. Significant topics include goal setting, time management, efficient and critical reading, note-taking, concentration and memory development, study techniques, test-taking, vocabulary development, and other skills needed in successful transitions associated with college life. The course provides hybrid learning.

It is on this premise that the researchers conceptualized this research study to assess hybrid learning as a pedagogical tool in a course called Strategies for Academic Success in College. The study includes the assessment of the learners in terms of learning design, objectives and outcomes, materials, technology, learning support, administrative and organizational commitment, physical interactions with students and professors, and lastly, the quantity and quality of the learning experiences of the learners. A test of significant differences in the assessments of the student-respondents taking said course shall be tested as a basis of more meaningful data interpretation and as a feeder to the proposed enhancement in the way hybrid learning is facilitated and delivered.

\subsection{Background of the Study}

With the introduction of the computer, the learning communities realized the potential of this powerful technology and adopted it as a new delivery tool. As the computer continued to evolve, a new generation of computer-mediated instruction arrived, and with the emergence of the Internet, new collaborative tools and delivery media appeared.

While hybrid learning as a concept and practice is not new, it is imperative to note how students take it as the learner characteristics keep on changing and that educational institutions need to become more adaptive and sensitive to the learning needs of all students. Currently, students and teachers experience much trouble and consume too much of their time in attending their classes on time. Most often than not, both teachers and students experience the dilemma of time constraints caused by specific concerns in demographics and geographical locations. As an intervention, Jose Rizal University and other institutions opted to mitigate such concerns as these affect or influence quality learning and instruction.

This study is relevant to the University's thrust, where the researchers are connected to become a market leader of innovative teaching and learning. The results will benefit the University to enhance its capacity to fulfill the vision and mission set through the new learning management system.

This study sought an understanding of how students assess their experiences in hybrid learning as a tool in FOS C101 or Strategies in Academic Success in College. Being the end-receivers of the teaching and learning cycle, the students' feedback is necessary to help improve learning and teaching delivery. Several areas of hybrid learning shall be assessed, such as learning design, learning objectives and outcomes, learning materials, technology, learning support, administrative and organizational commitment, amount and quality of physical interaction with students and professors, and quantity and quality of the learning experience.

The course explored in this study was the Freshmen Orientation Seminar, also known as Strategies for Academic Success in College. Only JRU offers said course being an institution granted with Institutional Autonomy by the Commission on Higher Education. FOS was offered in 2006. The course was delivered through face-to-face 
from its inception and eventually utilized hybrid learning through Canvas as its online platform.

In this study, the demographic profile of the respondents was taken into considerations, such as age, sex, current program enrolled in, senior high school strand finished, and the school where the respondents graduated. The demographic profile was used not only to provide a glimpse of the profile of the students but as variables in the exploration of differences in assessments in hybrid learning.

Hybrid learning is assessed in terms of learning design, learning objectives and outcomes, learning materials, technology, learning support, administrative and organizational commitment, amount and quality of physical interaction with students and professors, and quantity and quality of the learning experience, the findings of which are utilized in the test of significant differences between these areas and the students' current program enrolled.

The results of this study may help the University improve its teaching and learning delivery of FOS C101 through hybrid learning. Other universities may benefit from the findings so as to consider continuous assessment as a way of life while students are on the verge of online platforms.

\subsection{Research Questions}

The study assessed a hybrid learning approach in teaching the course, Strategies for Academic Success in College. Specifically, the study sought answers to the following questions:

1. What is the level of assessment of the respondents on hybrid learning as a pedagogical tool in teaching FOS C101: Strategies for Academic Success in College in terms of learning design, learning objectives and outcomes, learning materials, technology, learning support, administrative and organizational commitment, amount and quality of physical interaction with students and professors and quantity and quality of learning experiences?

2. If there are any, how significant are the differences in the levels of assessment of the respondents on hybrid learning on Strategies for Academic Success in College course when grouped according to their current program enrolled?

\subsection{Research Hypothesis}

$\mathrm{H}_{0}$ : There are no significant differences in the assessment of the respondents on hybrid learning on Strategies for Academic Success in College students when the respondents are grouped according to the current program enrolled. This was tested using the .05 alpha level of significance.

\section{Materials and Methods}

\subsection{Research Design}

The researchers used a descriptive-exploratory design. Descriptive method of research is a fact-finding with adequate interpretation and evaluative design. It is not mere data-gathering but a report on the meaning of the collected data against objectives and underlying assumptions of the project underway. Moreover, the descriptive research can only measure what already exists.

This research design was best suited in this study as the study only focuses on assessing hybrid learning as a pedagogical tool in teaching FOS C101 or Strategies in Academic Success in College, where variables are involved and can be measured using descriptive statistics.

\subsection{Research Sample}

The target respondents were freshmen students taking up FOS C101 under the supervision of the researchers who happened to be their professor in the said course of interest. These students take several baccalaureate degrees during the semester. There are 16 sections, but only eight sections were being handled by the researchers, and about 50 students were enrolled per class. From these, the respondents were selected accordingly using systematic random sampling by assigning numbers to all possible respondents. Per class, five student respondents were selected. To select the samples per class, the researchers decided to select every 10th, 20th, 30th, 40th, and 50th students as respondents based on the list of students from which the samples were chosen.

Random sampling technique was utilized because it is the most scientific among all probability sampling methods, as this gives everyone an equal chance to get selected as respondents of this study. In a random sampling technique, assigning a number to each of the target population eliminates the bias of selecting the samples from the target population.

The target population involved first year college students enrolled in FOS C101: Strategies of Academic Success in College at Jose Rizal University. From the population, the researchers used her eight classes in FOS C101 using proportionate sampling. In each class, five students were selected as respondents of the study, with a total of 40 respondents.

Data revealed that the majority of the respondents were aged $18-20$ years old, with $67.5 \%$. Least in the count were those aged $15-17$ years old with $10.0 \%$. As for their gender, $57.50 \%$ of the respondents were males, while $46.50 \%$ were females. In terms of the courses of the respondents, they were enrolled in FOS C101 with degrees in Bachelor of Science in Business Administration (BSBA) significant in Management, BSBA major in Accounting, Bachelor of Science in Accountancy (BSA), BSBA major in Finance, 
Bachelor of Science in Legal Management (BSLM), Bachelor of Science in Hotel and Restaurant Management (BSHRM), Bachelor of Science in Information Technology (BSIT), and Bachelor of Arts in Psychology (AB Psychology). Each course had five representatives as respondents. As to their Senior High School strand finished, $37.5 \%$ of the respondents were graduates of Humanities and Social Science (HUMSS), Science, Technology, Engineering and Mathematics (STEM) with 22.5\%, General Academic Strand (GAS) with 15\%, Technical-Vocational (TechVoc), and Accountancy, Business, and Management (ABM) and Technical-Vocational (TechVoc) with $12.5 \%$. In terms of the type of school where the respondents graduated, data showed that most of them were from public schools with $67.5 \%$ and $32.5 \%$ from private.

\subsection{Research Instrument}

To gather pertinent data and information needed for this study, the researchers used an adopted questionnaire (Padagas, 2012) with the approval of the author for its usage. The questionnaire consists of demographic profile and hybrid learning assessments.

For the demographic profile, the respondents' age, gender, the current program enrolled in, type of high school they graduated from, and SHS finished shall be determined. On the other hand, hybrid learning dimensions such as learning design, learning objectives and outcomes, learning materials, technology, learning support, administrative and organizational commitment, amount and quality of physical interaction with students and professors, and quantity and quality of the learning experience shall be assessed using a 5-point Likert Scale.

Each criterion was measured on a 5-point scale and the description used in assessing the given categories such as 5: Very high assessment; 4: High assessment; 3: Average assessment; 2: Low assessment; and 1: Very low assessment.

The means of the weighted responses were interpreted along the following scale and description (Table 1).

Table 1. Arbitrary Scale

\begin{tabular}{|l|l|l|}
\hline Rating & Range & Verbal Interpretation \\
\hline 5 & $4.01-5.00$ & Very high assessment \\
\hline 4 & $3.50-4.00$ & High assessment \\
\hline 3 & $2.50-3.49$ & Average assessment \\
\hline 2 & $1.50-2.49$ & Low assessment \\
\hline 1 & $1.00-1.49$ & Very low assessment \\
\hline
\end{tabular}

\subsection{Data Gathering Procedures}

The approval to conduct the study was ensured. The research instrument was personally distributed to the respondents and further enhanced by a written interview. During the data gathering, the researchers also obtained informed consent from the respondents. The informed consent assured no personal information of the respondents, such as names, addresses, and other personal pertinent information were to be divulged. This was an assurance of confidentiality and anonymity to any of the responses that they can be identified. Ethical considerations mattered to succeed data gathering as this protected the respondents with their rights to disclose their assessments about hybrid learning. It was emphasized further that their assessments will never ever affect any of their academic ratings and that this study was only intended to help improve the delivery of hybrid learning in FOS C101: Strategies for Academic Success in College.

The retrieval of the questionnaire was done. Information gathered was collated, interpreted, analyzed, and statistically treated.

\subsection{Treatment of Data}

Descriptive statistics were employed, such as frequency, percentage, mean scores, and weighted means. To determine significant differences in the level of assessment of the respondents when they were clustered according to their demographic profile variables, one-way analysis of variance (ANOVA) was used.

\section{Results and Discussions}

\subsection{Learning Design}

As assessed by the respondents, Table 2 presents the assessment of hybrid learning according to its learning design. It can be understood in the table that generally, the respondents assessed learning design High (WM: 3.87). Considerably, item \#3, which states that "Providing a learning design that is suitable for student activities" (MS: 4.15), got the highest mean score. This is to tell that the learning design of hybrid learning fits desirably for students. On the other hand, item \# 5 says, "Providing a learning design that is appropriate to each course being studied" (MS: 3.39) got the lowest. This means that students' assessment suggests that the appropriateness of the learning design in hybrid learning must be improved. The learning design is essential to the success of the blended learning course. Müller Werder \& Fengler (2019) reiterated that a blended learning design must allow students to increase flexibility as to when and where they study. 
Table 2. Assessment of Hybrid Learning according to Learning Design

\begin{tabular}{|l|l|l|}
\hline Items & Mean & Verbal Interpretation \\
\hline Providing a learning design specific to the learning needs of the students. & 3.45 & Average assessment \\
\hline Providing a learning design that maximizes student participation. & 4.13 & High assessment \\
\hline Providing a learning design that is suitable for student activities. & 4.15 & High assessment \\
\hline Providing a learning design that is easy to comprehend. & 3.40 & Average assessment \\
\hline Providing a learning design that is appropriate to each course being studied. & 3.39 & Average assessment \\
\hline Weighted Mean & 3.74 & High assessment \\
\hline
\end{tabular}

\subsection{Learning Objectives and Outcomes}

Table 3 presents the assessment of hybrid learning according to its learning objectives and outcomes. There is a high assessment given to this dimension of hybrid learning with a WM of 3.69. The data reveal that the item that states, "Providing learning outcomes and objectives that are realistic" (MS: 3.88), got the highest mean score. This means that the respondents believe that the learning outcomes and objectives are set realistically in their hybrid learning. It is interesting to note, however, that the learning outcomes and objectives must be attainable based on the respondents' assessment. Norman (2018) found out that learning outcomes include knowledge increase, self-confidence, satisfaction, and collaboration. It is further cited that students who are satisfied with their learning are more likely to engage actively and participate in the learning activity. Assessments of and for learning are conducted in many ways. Regardless of the strategies employed, for as long as desired learning outcome is achieved, learning remains a constant in the blended learning as a mode of instruction.

Table 3. Assessment of Hybrid Learning according to Learning Objectives and Outcomes

\begin{tabular}{|l|l|l|}
\hline Items & Mean & $\begin{array}{l}\text { Verbal } \\
\text { Interpretation }\end{array}$ \\
\hline $\begin{array}{l}\text { Providing learning outcomes and } \\
\text { objectives that are simple to } \\
\text { understand. }\end{array}$ & 3.75 & High assessment \\
\hline $\begin{array}{l}\text { Providing learning outcomes and } \\
\text { objectives that are measureable. }\end{array}$ & 3.70 & High assessment \\
\hline $\begin{array}{l}\text { Providing learning outcomes and } \\
\text { objectives that are attainable. }\end{array}$ & 3.38 & High assessment \\
\hline $\begin{array}{l}\text { Providing learning outcomes and } \\
\text { objectives that are realistic. }\end{array}$ & 3.88 & $\begin{array}{l}\text { Average } \\
\text { assessment }\end{array}$ \\
\hline $\begin{array}{l}\text { Providing learning outcomes and } \\
\text { objectives that are time-bounded. }\end{array}$ & 3.76 & High assessment \\
\hline Weighted Mean & 3.69 & High assessment \\
\hline
\end{tabular}

\subsection{Learning Materials}

It can be gleaned in Table 4 that the learning materials in hybrid learning got high assessment with a WM of 3.76 . The use of various learning materials maximizes the respondents' creativity with a mean score of 4.05 . On the other hand, the use of print and nonprint media must be reviewed to enhance the delivery of hybrid learning.
Generally, the learning materials in hybrid learning gained high assessment.

Table 4. Assessment of Hybrid Learning according to Learning Materials

\begin{tabular}{|l|l|l|}
\hline Items & Mean & $\begin{array}{l}\text { Verbal } \\
\text { Interpretation }\end{array}$ \\
\hline $\begin{array}{l}\text { Using various learning materials that } \\
\text { stimulate critical thinking. }\end{array}$ & 3.68 & High assessment \\
\hline $\begin{array}{l}\text { Using various learning materials that } \\
\text { maximize creativity. }\end{array}$ & 3.63 & High assessment \\
\hline $\begin{array}{l}\text { Using various learning materials that are } \\
\text { accessible and usable. }\end{array}$ & 4.05 & High assessment \\
\hline $\begin{array}{l}\text { Using various learning materials like } \\
\text { print (e.g. books, magazines, journals, } \\
\text { etc.) and non-print media (e.g. CD's, } \\
\text { videos, etc.) }\end{array}$ & 3.53 & High assessment \\
\hline $\begin{array}{l}\text { Using various learning materials that are } \\
\text { within the students' capacity to } \\
\text { understand. }\end{array}$ & 3.93 & High assessment \\
\hline Weighted Mean & 3.76 & High assessment \\
\hline
\end{tabular}

The findings supported the stipulations of Padagas (2012) when he posited that learning materials should be enhanced and updated to be able to deliver instruction more efficiently and more effectively in a hybrid learning environment. The implementation of blended learning in higher education is increasing, often intending to offer flexibility in terms of time and place to a diverse student population (Boelens et al. 2019).

\subsection{Technology}

Table 5. Assessment of Hybrid Learning according to Technology

\begin{tabular}{|l|l|l|}
\hline Items & Mean & $\begin{array}{l}\text { Verbal } \\
\text { Interpretation }\end{array}$ \\
\hline $\begin{array}{l}\text { Providing online resources for } \\
\text { students for their learning and } \\
\text { research. }\end{array}$ & 3.93 & High assessment \\
\hline $\begin{array}{l}\text { Providing easy access to available } \\
\text { electronics resources }\end{array}$ & 3.90 & High assessment \\
\hline $\begin{array}{l}\text { Providing user-friendly electronic } \\
\text { resources. }\end{array}$ & 3.88 & High assessment \\
\hline $\begin{array}{l}\text { Providing cost effective means of } \\
\text { sending and acquiring information } \\
\text { via email, blogs among others. }\end{array}$ & 4.15 & High assessment \\
\hline $\begin{array}{l}\text { Providing greater use of information } \\
\text { and communication technologies to } \\
\text { increase student networking. }\end{array}$ & 3.45 & High assessment \\
\hline Weighted Mean & 3.86 & High assessment \\
\hline
\end{tabular}


Table 5 shows the high assessment of hybrid learning in terms of technology. To provide cost-effective means of sending and acquiring information via email, blogs, among others, is necessary as revealed by the high assessment of this item with a mean score of 4.15. It is essential to note, on the other hand, that the accessibility and availability of electronic resources must be examined to maximize the use of hybrid learning in effect on the learning outcomes of the respondents. Generally, technology got high assessments among the respondents.

\subsection{Learning Support}

Table 6 reveals that learner support got a high assessment with WM of 3.85. Items state "Establishing a counseling section beyond information provision to academic concept, study habits, and other students' needs" and "Conducting regular formative evaluation in getting feedbacks from students to check level of satisfaction on the instructional and support services needed in the program" with both garnering a mean score of 4.15 . However, there is a dire need to enhance tutorial and assistance services as well as access to these services. This dimension must be efficient and responsive enough to address students' needs. Moreover, the teachers' presence during the course, his or her interactions with students, and the quality of the videos presented are significant determinants of course completion (Gregori et al., 2018).

Table 6. Assessment of Hybrid Learning according to Learner Support

\begin{tabular}{|l|l|l|}
\hline Items & Mean & $\begin{array}{l}\text { Verbal } \\
\text { Interpretation }\end{array}$ \\
\hline $\begin{array}{l}\text { Strengthening tutorials/assistance } \\
\text { services. }\end{array}$ & 3.39 & $\begin{array}{l}\text { Average } \\
\text { assessment }\end{array}$ \\
\hline $\begin{array}{l}\text { Establishing a counselling section } \\
\text { beyond information provision to } \\
\text { academic concept, study habits, and } \\
\text { other students' needs. }\end{array}$ & 4.15 & High assessment \\
\hline $\begin{array}{l}\text { Conducting regular formative } \\
\text { evaluation in getting feedbacks from } \\
\text { students to check level of satisfaction } \\
\text { on the instructional and support } \\
\text { services needed in the program. }\end{array}$ & 4.15 & High assessment \\
\hline $\begin{array}{l}\text { Equipping the host agencies/offices } \\
\text { with sufficient personnel, the best } \\
\text { possible facilities and resources to } \\
\text { help the students carry out their } \\
\text { studies effectively. }\end{array}$ & 3.75 & High assessment \\
\hline $\begin{array}{l}\text { Providing access to support services } \\
\text { of Jose Rizal University such as } \\
\text { scheduling, registration, and } \\
\text { record-keeping that are convenient, } \\
\text { efficient and responsive to students. }\end{array}$ & 3.83 & High assessment \\
\hline Weighted Mean & 3.85 & High assessment \\
\hline
\end{tabular}

\subsection{Organizational Commitment}

In terms of organizational commitment, Table 7 showcases that the respondents assessed hybrid learning with high assessment (WM: 3.85). The item that states
"Ensuring regular evaluation of the effectiveness of the policies, management practices and operational procedures of the program" got the highest mean score of 3.95. While the assessment of this dimension is high, it is imperative that administrative and support services must be consistent to ensure learning coherence. Administrative support, culture, instructional design, and faculty time may hinder blended learning (Aldosemani, Shepherd, \& Bolliger, 2019).

Table 7. Assessment of Hybrid Learning according to Organizational Commitment

\begin{tabular}{|c|c|c|}
\hline Items & Mean & $\begin{array}{l}\text { Verbal } \\
\text { Interpretation }\end{array}$ \\
\hline $\begin{array}{l}\text { Realizing the over-all mission of } \\
\text { Jose Rizal University in developing } \\
\text { useful and responsible citizens } \\
\text { through the effective use of } \\
\text { relevant knowledge and desirable } \\
\text { values. }\end{array}$ & 3.83 & High assessment \\
\hline $\begin{array}{l}\text { Providing administrative and } \\
\text { support services that are consistent } \\
\text { to ensure learning coherent } \\
\text { environment. }\end{array}$ & 3.80 & High assessment \\
\hline $\begin{array}{l}\text { Committing to research and } \\
\text { development for the instructional } \\
\text { delivery. }\end{array}$ & 3.83 & High assessment \\
\hline $\begin{array}{l}\text { Ensuring regular evaluation of the } \\
\text { effectiveness of the policies, } \\
\text { management practices and } \\
\text { operational procedures of the } \\
\text { program. }\end{array}$ & 3.95 & High assessment \\
\hline $\begin{array}{l}\text { Conducting student satisfaction } \\
\text { surveys to determine effectiveness } \\
\text { and efficiency of hybrid learning. }\end{array}$ & 3.85 & High assessment \\
\hline Weighted Mean & 3.85 & High assessment \\
\hline
\end{tabular}

\subsection{Amount and Quality of Interaction of Students and Teachers}

Table 8. Assessment of Hybrid Learning according to Amount and Quality of Interaction of Students and Teachers

\begin{tabular}{|l|l|l|}
\hline Items & Mean & $\begin{array}{l}\text { Verbal } \\
\text { Interpretation }\end{array}$ \\
\hline $\begin{array}{l}\text { Promoting meaningful physical } \\
\text { interaction among its students } \\
\text { and professors. }\end{array}$ & 3.78 & High assessment \\
\hline $\begin{array}{l}\text { Providing means to promote } \\
\text { student networking. }\end{array}$ & 3.50 & High assessment \\
\hline $\begin{array}{l}\text { Ensuring active participation } \\
\text { among students during } \\
\text { classroom session and } \\
\text { interactions via online. }\end{array}$ & 4.03 & High assessment \\
\hline $\begin{array}{l}\text { Ensuring a professional } \\
\text { interpersonal, and } \\
\text { relationship among students and } \\
\text { their professors. }\end{array}$ & 3.43 & High assessment \\
\hline $\begin{array}{l}\text { Promoting camaraderie, } \\
\text { cooperation and commitment } \\
\text { for self- directed and } \\
\text { independent learning. }\end{array}$ & 3.90 & High assessment \\
\hline Weighted Mean & 3.73 & High assessment \\
\hline
\end{tabular}


Table 8 presents the assessment of the respondents in terms of the amount and quality of interaction of students and teachers. Generally, this dimension was assessed highly. The item that states, "Ensuring active participation among students during classroom session and interactions via online" got the highest mean score of 4.03. However, ensuring a smooth interpersonal, professional relationship among students and their professors must be enhanced according to the results that got the lowest mean score of 3.43. Participation within online discussions is defined as the process where learners and educators are actively engaged in online text-based communication with each other.

\subsection{Quantity and Quality of Learning}

Table 9. Assessment of Hybrid Learning according to Quality and Quantity of Learning

\begin{tabular}{|c|c|c|}
\hline Items & Mean & $\begin{array}{l}\text { Verbal } \\
\text { Interpretation }\end{array}$ \\
\hline $\begin{array}{l}\text { Providing outstanding learning } \\
\text { experience necessary to build a } \\
\text { good career. }\end{array}$ & 3.85 & $\begin{array}{l}\text { High } \\
\text { assessment }\end{array}$ \\
\hline $\begin{array}{l}\text { Promoting quality learning to } \\
\text { realize potentials to be able to be } \\
\text { more productive in the workplace. }\end{array}$ & 3.05 & $\begin{array}{l}\text { Average } \\
\text { assessment }\end{array}$ \\
\hline $\begin{array}{l}\text { Providing adequate and meaningful } \\
\text { time to elicit learning. }\end{array}$ & 3.85 & $\begin{array}{l}\text { High } \\
\text { assessment }\end{array}$ \\
\hline $\begin{array}{l}\text { Increasing potentials to become } \\
\text { more self-directed when it comes to } \\
\text { managerial skills such as planning, } \\
\text { organizing, directing and } \\
\text { controlling. }\end{array}$ & 4.10 & $\begin{array}{l}\text { High } \\
\text { assessment }\end{array}$ \\
\hline $\begin{array}{l}\text { Guiding its students to be nationally } \\
\text { competitive. }\end{array}$ & 3.50 & $\begin{array}{l}\text { High } \\
\text { assessment }\end{array}$ \\
\hline Weighted Mean & 3.67 & $\begin{array}{l}\text { High } \\
\text { assessment }\end{array}$ \\
\hline
\end{tabular}

Table 9 presents the assessment of the respondents according to the quality and quantity of learning experience. The data posit that there is an increasing potential to become more self-directed when it comes to managerial skills among the respondents. The item that states, "Promoting quality learning to realize potentials to be able to be more productive in the workplace" got the lowest mean score of 3.05. The inclusion of lifelong learning experiences is essential to help students value their learning in a hybrid learning environment.

\subsection{Significant Differences}

Table 10 shows the significant differences of the various dimensions of hybrid learning when the respondents are clustered according to their courses (i.e., Bachelor of Science in Business Administration (BSBA) major in Management, BSBA major in Accounting, Bachelor of Science in Accountancy (BSA), BSBA major in Finance, Bachelor of Science in Legal Management (BSLM), Bachelor of Science in Hotel and Restaurant Management (BSHRM), Bachelor of Science in Information Technology (BSIT), and Bachelor of Arts in Psychology (AB Psychology).

The data show that age and learning design, learning objectives and outcomes, learning materials, technology, learner support, administrative and organizational commitment, amount and quality of interaction between teachers and students, and quality and amount of learning experience are not significantly related.

This means that regardless, of course, the respondents do not vary with their assessments of hybrid learning.

Table 10. Significant Differences in the Assessment of Hybrid Learning and Respondents' Courses

\begin{tabular}{|l|l|l|l|l|}
\hline Courses & F-test value & p-value & Decision & Remarks \\
\hline Learning design & 1.405 & 0.237 & Fail to reject $\mathrm{H}_{0}$ & Not significant \\
\hline $\begin{array}{l}\text { Learning objectives and } \\
\text { outcomes }\end{array}$ & 2.116 & 0.070 & Fail to reject $\mathrm{H}_{0}$ & Not significant \\
\hline Learning materials & 1.254 & 0.304 & Fail to reject $\mathrm{H}_{0}$ & Not significant \\
\hline Technology & 0.803 & 0.592 & Fail to reject $\mathrm{H}_{0}$ & Not significant \\
\hline Learning support and & 1.706 & 0.143 & Fail to reject $\mathrm{H}_{0}$ & Not significant \\
\hline $\begin{array}{l}\text { Administrative } \\
\text { organizational commitment }\end{array}$ & 1.413 & 0.234 & Fail to reject $\mathrm{H}_{0}$ & Not significant \\
\hline $\begin{array}{l}\text { Amount and quality of } \\
\text { interaction between teachers } \\
\text { and students }\end{array}$ & 0.360 & 0.919 & Fail to reject $\mathrm{H}_{0}$ & Not significant \\
\hline $\begin{array}{l}\text { Quality and amount of learning } \\
\text { experience }\end{array}$ & 0.617 & 0.738 & Fail to reject $\mathrm{H}_{0}$ & Not significant \\
\hline
\end{tabular}




\section{Conclusions}

The proposition of whether or not hybrid learning can replace the traditional classroom is an overstatement. While the findings of this study revealed a high level of assessment in using hybrid learning as a tool of instruction in FOS C101 in terms of learning design, learning objectives and outcomes, learning materials, technology, learner support, administrative and organizational commitment, amount and quality of interaction between teachers and students, and quality and amount of learning experience, it is still a course of debate whether it can really supplant traditional method of instruction. It is far more essential to conclude that hybrid learning can be used as an alternative modality in teaching FOS C101, the way other courses have used in so many years. Substantially, technology can complement the traditional model of teaching and learning, but it does not necessarily mean replacing the teacher in a brick-and-stone classroom setting.

Out of the findings of this study, the researchers recommend applying a more effective learning design for the course. Realignment must be ensured to maximize hybrid learning as a tool of teaching. While the learning objectives and outcomes are realistic, this dimension must be set in a more attainable manner. Secondly, the use of various learning materials like print (e.g., books, magazines, journals, etc.) and non-print media (e.g., CD's, videos, etc.) in hybrid learning must be reinforced accordingly. Thirdly, enhance the accessibility of electronic resources. Updating of instructional materials with sufficient personnel and selection of qualified faculty, the best possible facilities and resources help the students carry out their studies effectively. Moreover, institutions and academic units should provide and actively promote training for students in the use of technologies that students will use in their courses. Likewise, institutions that offer online courses or programs should make an effort to present faculty the research about the efficacy of hybrid learning to use online tools for achieving student learning outcomes. Furthermore, ensure a smooth interpersonal, professional relationship among students and their professors. Teachers should also be retooled to utilize and maximize hybrid learning towards quality student education. Padagas et al. (2019) cited that to improve delivery, the online platforms must intensify co-creation among the students and teachers to maximize utilization despite reverberating challenges. Lastly, relevant research studies can be conducted further using a broader scope and population sample.

\section{Acknowledgments}

The researchers extend their sincerest thanks to all those who have contributed in the conduct and completion of this research.

\section{REFERENCES}

[1] LeBlanc, P. (2019, April 5). New Hampshire to Nairobi: SNHU is Scaling Breakthrough Learning. Retrieved April 8, 2020, from https://www.snhu.edu/about-us/newsroom/201 9/04/from-new-hampshire-to-nairobi-how-snhu-is-scalingbreakthrough-learning-for-all-students)

[2] Padagas, Reynold C. (2012). Hybrid e-learning: An alternative learning strategy at Jose Rizal University. Jose Rizal University, Mandaluyong City, Philippines.

[3] Müller Werder, C., \& Fengler, R. (2019). Implementation of a flexible learning study programme in a blended-learning design: results from the first two cohorts. In EDEN 2019 ANNUAL Conference, Bruges, Belgium, 16-19 June 2019 (pp. 1-9). European Distance and E-Learning Network.

[4] Norman, J. (2018). Differences in learning outcomes in simulation: The observer role. Nurse education in practice, $28,242-247$.

[5] Boelens, R., Voet, M., \& De Wever, B. (2018). The design of blended learning in response to student diversity in higher education: Instructors' views and use of differentiated instruction in blended learning. Computers \& Education, 120, 197-212.

[6] Gregori, E. B., Zhang, J., Galván-Fernández, C., \& de Asís Fernández-Navarro, F. (2018). Learner support in MOOCs: Identifying variables linked to completion. Computers \& Education, 122, 153-168.

[7] Aldosemani, T., Shepherd, C. E., \& Bolliger, D. U. (2019). Perceptions of Instructors Teaching in Saudi Blended Learning Environments. TechTrends, 63(3), 341-352.

[8] Padagas, R., Gutierrez, R., Trangia, L. When Technology Disrupts Teaching and Learning: A Private Higher Education Students' Perceptions on the Challenges of Technology-based Teaching Tool. Universal Journal of Educational Research 7.11 (2019) 2293 - 2302. doi: 10.13189/ujer.2019.071107. 